\title{
SUSTAINABLE DEVELOPMENT AND RELIGION: ACCOMMODATING DIVERSITY IN A POST-SECULAR AGE
}

\author{
Accepted for publication 29 May 2016 in
}

The Review of Faith and International Affairs

\begin{abstract}
Alastair Ager and Joey Ager
Alastair Ager has worked in the field of international development - with a focus on refugees and internally displaced communities - for 25 years, after originally training in psychology at the universities of Keele, Wales and Birmingham in the UK. He has wide international experience across sub-Saharan Africa, south Asia, Europe, and North America, having worked as a consultant for agencies, including UNICEF, UNHCR, Save the Children, World Vision, Oxfam, and Child Fund International. He is Director of the Institute for Global Health and Development, Queen Margaret University, Edinburgh and Professor of Population and Family Health, Columbia University, USA
\end{abstract}

Joey Ager studied theology at Oxford University, with a focus on African theologies of liberation. He has worked with Sojourners, a faith-based social justice organization in Washington, DC, with Ember Arts, promoting women's livelihoods in Uganda through fair trade, and as a researcher for the Joint Learning Initiative Hub on Resilience and Local Faith Communities. He is currently working as a community organizer with SDOP, a member of the PICO network of faith communities organizing around justice issues across the USA.

\section{Sustainable Development and Religion: Accommodating Diversity in a Post-Secular Age}

With the abandonment of the secularization thesis which assumed religion would become increasingly marginal with economic development and modernization, development theory is having to come to terms with global plurality in a context where the secular is no longer accepted as a neutral frame. Indeed, the resurgence of religion can be seen as the major source of challenge to neoliberal hegemony in development thinking. How can development assistance respond to these fundamental shifts in understanding? Is recognition of the dawning of a postsecular age a signal for the further fragmentation of global consensus on developmental goals, or an opportunity to recognize the strengths of diversity and the value of religion in shaping visions of non-consumption-based development?

The resurgence of interest in religion in the context of international development is to be welcomed but is marked by significant ambiguity. On one hand, interest reflects a broader reawakening to the significance of religion in public affairs. Scott Thomas and Timothy Shah, among others, have documented this transition in the field of international relations where, from a position of general neglect, consideration of religion and religious actors has become explicitly mainstream (Thomas 2005; Toft, Philpott, and Shah 2011; Shah, Stepan, and Toft 2012). Within the arena of political science there has been growing attention to religion and its expression within contexts marked - through the combined influences of globalization and migration-by increasing plurality (Bhargava 1998).

The development sciences can point to similar advances. For example, anthropologicallyinformed analysis of local processes and meanings shaping community engagement, always a core stimulus to development thinking, has increasingly addressed religious discourse and groups 
(Tomalin 2015). The World Bank began strategic exploration of engagement with faith institutions in the late 1990s (Wolfensohn 1999), in work that laid the groundwork for the establishment of the World Faiths Development Dialogue in 1998 and, more recently, cosponsorship of the 2015 Religion and Sustainable Development meeting with USAID, the German government and other donors.

On the other hand, global development continues to be peculiarly wedded to a modernist, secular frame. While the confident modernism of the mid- $20^{\text {th }}$ century has largely been abandoned within the social and political sciences, the formulation of the MDGs and, latterly, the SDGs reflects continued commitment to a potential 'grand narrative' binding global actors to a common cause. Current development discourse fundamentally retains an epistemological commitment to modernity, while political, social, and cultural thinking grapples with the consequence of its demise. Scholarship has come to challenge settled notions of secularism, either in terms of the structures, policies and processes that define the secular state or, more generally, regarding the notion that economic and social development inevitably results in the diminution of engagement with religion (Shakman Hurd 2008). This so-called secularization thesis is generally acknowledged to be firmly "debunked", even by those involved in its original formulation (Rakodi 2015). Developmentalists, however, generally continue to operate as if the tenets of secularism were sacrosanct principles (Fountain 2015; Ager and Ager 2015).

This adoption of a secular, modern frame is understandable if one sees developmental discourse as principally driven by the agendas of bilateral and multilateral development institutions pursuing international cooperation within the global architecture established in the wake of World War II. The formation of the United Nations, the development of international humanitarian law, and the establishment of the Bretton-Woods institutions all bear the mark of mid-twentieth century modernism. For many this is seen as a badge of honor rather than any basis for reproof. Indeed, the peace and cooperation established during the latter half of the twentieth century can be seen to owe much to the global governance and shared values encapsulated in these developments. Secularism served as pragmatic frame for a modernist agenda wrestling with the challenges of plurality in a rapidly globalizing world. The marginalization of religion would for many be seen as a small price to pay for this peace dividend.

However, the complex realities of the $21^{\text {st }}$ century raise the question of whether secularism is a feasible strategy to continue to manage plurality. In particular, in its current form, secularism serves to marginalize institutions crucial to the goal of sustainable development. Further, the claim that secularism serves as a neutral frame above and beyond the contested territory of values and belief is increasingly open to challenge. To substantiate these claims, it is necessary to consider more closely our understanding of the secular frame and its implications for analysis and engagement with religion.

Charles Taylor distinguishes between three meanings of the term secular (Taylor 2007). One relates to constitutional organization at the level of the state with respect to religious expression, while another refers to a condition of reduced religious belief and practice within a society. It is the third meaning, however, that is of greatest interest to him, and to us here. Linked to, but distinguishable from, the others this refers to "a context of understanding" that establishes certain conditions for belief (Taylor 2007, 7). Taylor's analysis in A Secular Age and elsewhere is not principally about spaces, nor about religious affiliation, but is rather about the assumptive world that the West has come to share. This "way of thinking" established within global elites bears the hallmarks of its trajectory through the evolution of Christian and post-Christian 
thought, Western social and economic development, and liberal political philosophy. However, it is peculiarly lacking in self-awareness of the particularity of its origins, and about the weakness of its claims of self-evident universality (Ager and Ager 2011).

This blindness of secularism to its presumptions has an impact on many aspects of public behaviour, but its implications for the understanding of, and approach to, religion is of greatest interest here. We can distinguish three major processes that are driven from this secular foundation of thinking: respectively the privatization, marginalization and instrumentalization of religion. Privatization involves the imposition of the Western dualism that separates understanding of the physical and spiritual, and restricts public expression regarding the latter. This separation violates many religious narratives regarding the integration of the sacred and the profane. This creates not only epistemological and theological tensions but also a practical distortion of the mission of faith-based development workers and agencies who are forced to cleave worldly actions from spiritual sentiments in a manner completely alien to non-western religious traditions. Marginalization is reflected by the language and fora for development that exclude opportunities for challenge from outside of this settled secular discourse. This leads to instrumentalization: the activities and resources seen to be relevant to the secular development agenda are utilized or, arguably, exploited, while the commitments, principles and dynamics that gave rise to them are denied.

There is increasing evidence, therefore, that within the development sector the adoption of a secular discourse - and the failure to openly engage with religious plurality-reflects a hegemonic impulse that generalizes the particularities of a western post-Christian frame of thinking. The concern here, however, is not about abstract epistemological tensions. This impulse fundamentally disempowers the voices - and the diverse traditions and understanding from which they are drawn - of the southern actors who have the greatest stake in the sustainable development enterprise.

One of the most cited studies in this field in recent years is that of the Pew Foundation and their estimate that over $80 \%$ of the global population identifies with some religious group or tradition (Hackett et al. 2012). With projections that this proportion is likely to grow in the coming years, this has been seen as key evidence regarding the demise of the secularization thesis and its understanding of processes of modernization and development. However, that this figure jars for so many with the language and presumptions of the contemporary development sector also raises questions regarding the voices of those shaping this discourse. Reflecting on the mirror distributions of religious affiliation indicated by the Pew report and the funding and staffing base of global development institutions suggests that we might presume that those voices (or the powers that shape their expression) are disproportionately drawn from the minority reporting no religious affiliation. Are these voices best seen as from progressive, educated elites steering the global community away from prejudice, conservatism and superstition, or as drawn from a class socialized into a narcissistic, neoliberal individualism committed to overconsumption? The authorial voice of the IFRC 2014 World Disaster Report on Climate and Risk, for example, would clearly wish to be viewed as the former, noting how:

In many parts of the world, particularly those where local cultural practices and worldviews are deeply embedded in everyday life [sic], beliefs often exert considerable influence on the ways that people perceive risks and respond to them (IFRC 2014, 44). 
However, beliefs, it becomes apparent here, are things that 'others' have, as: "Belief systems generally play no part in national-level policy relating to environment risk or longerterm environmental threats" (IFRC 2014, 52).

As we have noted elsewhere, this framing renders neoliberal presumptions regarding economic growth, personal freedoms, patterns of consumption, limits of redistribution of wealth, accountability to populations in low-income counties impacted by historical carbon emissions from high-income nations, and the like-all key to formulating strategies for sustainable development - as "beyond belief". Seeing such views as taken-for-granted realities, rather than constructions where "cultural practices and worldviews ... deeply embedded in everyday life... exert considerable influence on the ways that people perceive risks" (Ager and Ager 2015, 48), insulates a presumptive modernist discourse from critique regarding its partiality, positionality and historicity. It is a hegemonic act that delegitimizes certain presumptions and legitimizes others, all within the guise of providing a neutral space for shared deliberation.

Reluctance to recognize the dawning of a post-secular age can thus be seen as a strategy to preserve the hegemonic power of economically and politically powerful nations who seek to conform the global diversity of worldviews to a secular frame amenable to their continuing economic dominance and, increasingly pertinent, security.

However, is marginalizing plural voices a greater threat to stability and security than their deliberate and open inclusion? Recent strategic initiatives led by the German Federal Ministry of Development and Cooperation are an interesting case study in this respect. The German government has now established engagement with religious actors as a core pillar of its development strategy. Along with other donors, they have established the Partnership for Religion and Sustainable Development to facilitate "formalized exchange between donor nations, international organizations and religious actors to develop new forms of cooperation" (BMZ 2016, 15).

It is too early to say whether this just represents the latest instrumentalist strategy to coopt civil society actors to a pre-set agenda dominated by the interests of the G8. However, there are some interesting aspects of the modalities and language of the initiative which suggest a more serious engagement with diversity. The stated objective: "to drive forward the implementation of value-based development policy while also ensuring that religion's significance as an important source of values gains greater recognition in development policy and international cooperation" (GIZ 2015, 1) is promising in terms of the preceding analysis, as is the relative sophistication and confidence in engaging with the concept of secularism: "The state's neutral stance towards religions and beliefs does not imply neutrality towards value" (GIZ 2015, 1). The publication linked to the launch of this initiative, Religion and Development: Voices from Religions on the 2030 Agenda for Sustainable Development (GTZ 2016) offers multiple visions of a mutual, communitarian, non-consumptive basis for development and wellbeing. Grouped by the core domains of people, planet, peace and prosperity, it reflects something of the rich diversity of insights from religious traditions relevant to the goal of shared sustainable development.

To be of influence such voices need to be engaged within their diversity and not with respect to the narrow framing of a 'common agenda'. These voices need to challenge and to clash-within a safe space of shared interests - if they are to challenge current beliefs and presumptions of global elites rather than simply accommodate them. To create that dialogical engagement - and see shared action agendas emerge by embracing diversity rather than forcing 
adherence to a discredited, unsustainable modernist agenda-will be to embrace the post-secular age. 


\section{References}

Ager, Alastair, and Joey Ager. 2011. "Faith and the Discourse of Secular Humanitarianism." Journal of Refugee Studies 24 (3):456-72.

Ager, Alastair, and Joey Ager. 2015. Faith, Secularism, and Humanitarian Engagement: Finding the Place of Religion in the Support of Displaced Communities. New York: Palgrave Macmillan.

Bhargava, Rajeev. 1998. Secularism and its Critics. Oxford: Oxford University Press.

BMZ. 2016. "Religious Communities as Partners for Development Cooperation." In Strategy Paper. Berlin: Federal Ministry for Economic Cooperation and Development.

Fountain, Philip. 2015. "Proselytizing Development." In The Routledge Handbook of Religions and Global Development, edited by Emma Tomalin. Abington: Routledge.

GIZ. 2015. "Sector Programme Values, Religion and Development: Recognising and Harnessing the Potential of Religion." In Strategy Paper. Berlin: German Federal Ministry for Economic Cooperation and Development.

GTZ. 2016. "Partners for Change: Religions and the 2030 Agenda for Sustainable Development" Conference in Berlin, February 2016. Sponsored by the German Federal Ministry for Economic Cooperation and Development.

Hackett, Conrad, Brian Grim, Marcin Stonawski, Vegard Skirbekk, and Michaela Potančoková. 2012. "The Global Religious Landscape." In Pew Research Center's Forum on Religion \& Public Life. Washington, D.C.: Pew Research Center.

IFRC (International Federation of Red Cross Red Crescent). 2014. World Disasters Report: Focus on Culture and Risk. Geneva: International Federation of Red Cross Red Crescent.

Rakodi, Carole. 2015. "Development, Region and Modernity." In Routledge Handbook of Religions and Global Development, edited by Emma Tomalin. Abingdon: Routledge.

Shah, Timothy Samuel, Alfred Stepan, and Monica Duffy Toft. 2012. Rethinking Religion and World Affairs: USA New York: Open University Press.

Shakman Hurd, Elizabeth. 2008. The Politics of Secularism in International Relations. Princeton: Princeton University Press.

Taylor, Charles. 2007. A Secular Age. Cambridge: Harvard University Press.

Thomas, Scott. 2005. The Global Resurgence of Religion and the Transformation of International Relations: The Struggle for the Soul of the Twenty-first Century. New York: Palgrave Macmillan. 
Toft, Monica Duffy, Daniel Philpott, and Timothy Samuel Shah. 2011. God's Century: Resurgent Religion and Global Politics. New York: WW Norton \& Company.

Tomalin, Emma. 2015. The Routledge Handbook of Religions and Global Development. Abingdon: Routledge.

Wolfensohn, James D. 1999. A Proposal for a Comprehensive Development Framework [for World Bank policy]:A Discussion Draft. Washington, D.C.: The World Bank. 